\title{
Successful pregnancies after transfer of embryos recovered from ewes induced to ovulate 24-29 days post partum
}

\author{
J. M. Wallace, J. J. Robinson and R. P. Aitken \\ The Rowett Research Institute, Greenburn Road, Bucksburn, Aberdeen AB2 9SB, UK
}

\begin{abstract}
Summary. After lambing in late November, oestrus and ovulation were induced by using a CIDR device and PMSG in early weaned $(\mathrm{N}=13)$ or lactating $(\mathrm{N}=14)$ Border Leicester $\times$ Scottish Blackface ewes between 23 and 29 days after parturition. Ewes were intrauterine inseminated under laparoscopic visualization $54-55 \mathrm{~h}$ after CIDR-device withdrawal and eggs recovered on Day 3 of the cycle. Ovum recovery and fertilization rates were higher in lactating than in early weaned ewes, with fertilization being achieved as early as 24 days post partum in both groups. Of the 7 early weaned and 11 lactating ewes yielding eggs, fertilization occurred in 4 and 7 ewes respectively. A total of 20 embryos were transferred to the normal uterine environment of 15 recipient ewes in which the interval from parturition was $>150$ days. Pregnancies were successfully established in 9 recipient ewes, resulting in the birth of 10 viable lambs.

Prolactin concentrations were significantly higher $(P<0.001)$ in lactating than in early weaned ewes throughout the study. Nevertheless, normal luteal function (as assessed by daily progesterone concentrations) was exhibited by 12 of 14 lactating and 8 of 13 early weaned ewes. Two post-partum donors in which the corpora lutea completely failed to secrete progesterone yielded fertilized eggs which developed to term when transferred to a normal uterine environment.

The results show that sheep oocytes can be fertilized using laparoscopic intrauterine insemination as early as 24 days after parturition and that the resulting embryos are viable when recovered on Day 3 after oestrus and transferred to a normal uterine environment.
\end{abstract}

Keywords: post partum; fertilization; embryo viability; pregnancy; sheep

\section{Introduction}

The use of laparoscopic insemination to deposit semen directly into the tip of the uterine horn, thus bypassing the involuting uterus, has been shown to be effective in reducing the interval from parturition to successful fertilization in lactating ewes (McKelvey et al., 1989). However, despite successful fertilization and early cleavage of the embryos in $55 \%$ of ewes yielding eggs, following an induced oestrus 28 days after parturition, no pregnancies were sustained when the embryos were returned to their respective post-partum donors.

Although the incidence of inadequate luteal function, as determined by daily progesterone concentrations in peripheral blood is high in the early post-partum ewe, at least $60 \%$ of ewes with an induced oestrus 21 days post partum exhibit normal luteal function with progesterone concentrations identical to those observed in ewes in which the interval from parturition is $>150$ days (Wallace et al., 1989a, b). This suggests that inadequate luteal function is not the only factor limiting the establishment of pregnancy in the post-partum ewe. Indeed, the transfer of good quality embryos into post-partum recipient ewes induced to ovulate 21 days after parturition and exhibiting normal luteal function failed to result in the establishment of pregnancy, suggesting that 
at this time the involuting uterus of the early post-partum ewe is an inappropriate environment for embryo development (Wallace et al., 1989a).

The present study was carried out to determine how early after parturition fertilized eggs can be recovered from ewes and whether they can survive to term when transferred to the normal uterine environment of recipient ewes in which the interval from parturition was $>150$ days.

\section{Materials and Methods}

\section{Experimental design}

Donor ewes. The 27 Border Leicester $\times$ Scottish Blackface ewes, aged 3-6 years, which had been inseminated at a synchronized oestrus were each injected with $15 \mathrm{mg}$ betamethasone (Betsolan: Glaxovet plc, Greenford, Middlesex, UK) on Day 142 of pregnancy to induce parturition. Lambings occurred $24-72 \mathrm{~h}$ later between 19 and 21 November corresponding to mid-breeding season. The ewes, average litter size $1.8 \pm 0 \cdot 14$, were individually penned at the Rowett Researh Institute at $57^{\circ} \mathrm{N} 2^{\circ} \mathrm{W}$ and were offered $2.8 \mathrm{~kg}$ per day of a complete diet supplying $9 \mathrm{MJ}$ of metabolizable energy $/ \mathrm{kg}$.

Immediately after lambing the ewes were allocated to one of two groups on the basis of weight and litter size. Lambs were weaned within $48 \mathrm{~h}$ of parturition from 13 of the ewes (early weaned group) while the remaining 14 ewes lactated throughout the study. The ewes were induced to show oestrous behaviour between Days 23 and 29 post partum (mean \pm s.e.m., $26.6 \pm 0.42$ days). Synchronization of oestrus was achieved by withdrawing a progesteroneimpregnated controlled internal drug-release device (CIDR; containing $0.3 \mathrm{~g}$ progesterone; AHI Plastic Moulding Co., Hamilton, New Zealand) 11 days after their insertion. At withdrawal of the CIDR device each ewe received an i.m. injection of 750 i.u. PMSG (Intervet Laboratories, Cambridge, UK). Onset of oestrus was assessed using a vasectomized ram at 6-h intervals between 24 and $54 \mathrm{~h}$ after CIDR-device withdrawal. All ewes were inseminated into the uterus 54-55 h after CIDR withdrawal as described by McKelvey et al. (1985). Fresh semen was diluted 5:1 (v/v) with phosphate-buffered saline and $0.3 \mathrm{ml}$ was placed at the tip of each uterine horn. The composition of phosphatebuffered saline was $8.0 \mathrm{~g} \mathrm{NaCl}, 0.2 \mathrm{~g} \mathrm{KCl}, 0.132 \mathrm{~g} \mathrm{CaCl}_{2} .2 \mathrm{H}_{2} \mathrm{O}, 0.2 \mathrm{~g} \mathrm{KH}_{2} \mathrm{PO}_{4}, 0.1 \mathrm{~g} \mathrm{MgCl}_{2} \cdot 6 \mathrm{H}_{2} \mathrm{O}$ and $1.383 \mathrm{~g} \mathrm{Na}_{2} \mathrm{H}-$ $\mathrm{PO}_{4} \cdot 2 \mathrm{H}_{2} \mathrm{O}$ per litre distilled water. At laparotomy on Day 3 of the oestrous cycle the corpora lutea were counted and the eggs were recovered by the standard technique of retrograde flushing of the tip of the uterine horn (Hunter et al., 1955 ), held at $37^{\circ} \mathrm{C}$ in ovum culture medium (Flow Laboratories, Irvine, UK) and transferred within $1 \mathrm{~h}$ of recovery to synchronous recipients.

Recipient ewes. Border Leicester $\times$ Scottish Blackface ewes in which the interval from previous parturition was $>150$ days were used to receive embryos from the recently lambed donors. Synchronization of the recipients was achieved by withdrawing progestagen-impregnated pessaries (Chronogest: Intervet) 12 days after their insertion. At pessary withdrawal each ewe received 500 i.u. PMSG. Onset of oestrus was assessed using a vasectomized ram at 6-h intervals between 24 and $54 \mathrm{~h}$ after pessary withdrawal. At laparotomy on Day 3 of the cycle recipient ewes received either $1(\mathrm{~N}=10)$ or $2(\mathrm{~N}=5)$ embryos depending on availability. Embryos were transferred into the tip of the uterine horn.

Ewes diagnosed pregnant by progesterone analysis were scanned using ultrasound at Day 45 to determine fetal numbers. Lambing data were recorded at term.

Blood samples were taken daily from all donor ewes from Day 1 post partum until 20 days after induction of oestrus. Recipient ewes were sampled for 20 days after induction of oestrus. All daily samples from donor and recipient ewes were assayed for prolactin and progesterone. After CIDR-device or pessary withdrawal all ewes were sampled at 6-h intervals from +24 to $+96 \mathrm{~h}$ to determine the time of onset of the preovulatory $\mathrm{LH}$ surge. These samples were assayed for LH only.

Hormone assays. $\mathrm{LH}$ and prolactin were measured in duplicate by specific double-antibody radioimmunoassays as described previously (McNeilly \& Andrews, 1974; McNeilly et al., 1986). The sensitivities of the assays were $0.05 \mathrm{ng}$ LH (NIADDK-oLH-25)/ml and 0.08 ng prolactin (NIADDK-oPRL-17)/ml. The intra- and inter-assay coefficients of variation were 6.5 and $9.1 \%$ and 4.9 and $9.9 \%$ for $\mathrm{LH}$ and prolactin respectively. Progesterone concentrations were measured in $100 \mu \mathrm{l}$ samples of plasma by radioimmunoassay as described by Djahanbahkch et al. (1981). The intraassay coefficient of variation was $13.9 \%$, the detection limit was $0.3 \mathrm{ng} / \mathrm{ml}$ and the recovery of progesterone from plasma was $71 \cdot 7 \%(n=1200)$. Individual estimates of recovery were carried out on every sample and the necessary adjustments were made to the subsequent progesterone concentration estimate.

\section{Statistical analysis}

Where appropriate, results were analysed using $\chi^{2}$ tests, Student's $t$ test or a combination of one-way analysis of variance followed by Duncan's new multiple range test. The preovulatory LH surge was considered to have occurred when LH levels exceeded $10 \mathrm{ng} / \mathrm{ml}$. 


\section{Results}

\section{Oestrus and ovulation rate in donor ewes}

All 27 post-partum donor ewes exhibited behavioural oestrus after removal of the CIDR device and, at laparotomy on Day 3 of the subsequent cycle, all had evidence of having recently ovulated. Data for the onset of oestrus and the LH surge relative to CIDR-device withdrawal, the LH surge to intrauterine insemination interval and ovulation rate are presented in Table 1. Mean onset of oestrus was significantly later $(P<0.02)$ in lactating than in early weaned ewes. As ewes were inseminated at a fixed time from CIDR withdrawal it is not surprising that this longer interval to oestrus also resulted in a significantly shorter $(P<0.01)$ LH surge to insemination interval. In addition to comparing the effects of early weaning versus suckling on the above parameters the results were analysed (independent of suckling treatment) according to whether or not eggs were recovered from post-partum donor ewes and whether these eggs were fertilized. Ewes yielding fertilized eggs had a longer interval to the onset of oestrus $(P<0.05)$ and the LH surge $(P<0.05)$ compared with ewes from which no eggs were recovered (Table 1). Ovulation rate was independent of weaning/suckling treatments and was not correlated with ova recovery or fertilization rate.

\section{Ovum recovery, fertilization rate and pregnancy rate after embryo transfer}

Ovum recovery and fertilization rates were higher in lactating than in early weaned ewes (Table 2). There was no evidence of partial fertilization within uterine horns or in ewes as a whole. Similarly, there was no evidence of an effect of the number of fetuses carried in the previous pregnancy on the ability to recover ova after oestrus induced between Days 23 and 29 post partum. Fertilized eggs were recovered from ewes which had previously lambed singletons, twins and triplets (Table 3). Unfertilized eggs were recovered from the 2 ewes induced to show oestrus and inseminated on Day 23 post partum but the earliest stage at which fertilized eggs were recovered was on Day 24 post partum.

Fertilized eggs recovered from 11 post-partum donors were transferred to 15 recipient ewes in which the interval from parturition exceeded 150 days: 5 ewes received 2 embryos and 10 received a single embryo (Table 3). The mean interval from pessary withdrawal to onset of oestrus for the 15 recipient ewes was $34.4 \pm 0 \cdot 14 \mathrm{~h}$ and the mean ovulation rate was $2 \cdot 2 \pm 0 \cdot 14$. The degree of synchrony between donor and recipient ewes was high, as estimated from the differences in the timing of the LH-surge onset (Table 3). Successful pregnancies were established in 9 recipient ewes resulting in the birth of 1 pair of twins and 8 singleton lambs. Only one of the lambs born had originated from an early weaned post-partum donor. All lambs were viable at birth and the mean birth weight of the singleton lambs, expressed as $\mathrm{g} / \mathrm{kg}$ body weight $(\mathrm{w})^{0.75}$ of the recipient ewe at the time of transfer, was $277 \cdot 8 \pm 13 \cdot 16 \mathrm{~kg} \mathrm{~W}^{0 \cdot 75}$. These values are above those predicted from the data presented by Donald \& Russell (1970).

\section{Progesterone concentrations}

Post-partum donors. Daily peripheral progesterone concentrations increased immediately following CIDR-device insertion and thereafter values remained constant for the 11 days the devices were in situ, resulting in peripheral concentrations of $1-2 \mathrm{ng} / \mathrm{ml}$. Mean progesterone concentrations during CIDR-device synchronization of oestrus were similar in early weaned and lactating ewes, were independent of stage post partum over the range of 6 days studied, and were not correlated with subsequent ovum recovery or fertilization rates.

After synchronization of oestrus the subsequent corpus luteum function was assessed by measuring daily peripheral progesterone concentrations. Normal luteal function was defined as an increase in progesterone concentrations starting within 6 days of behavioural oestrus and rising to exceed $1 \mathrm{ng} / \mathrm{ml}$ for at least 8 days thereafter (based on McLeod et al., 1983). Using these criteria 
J. M. Wallace et al.

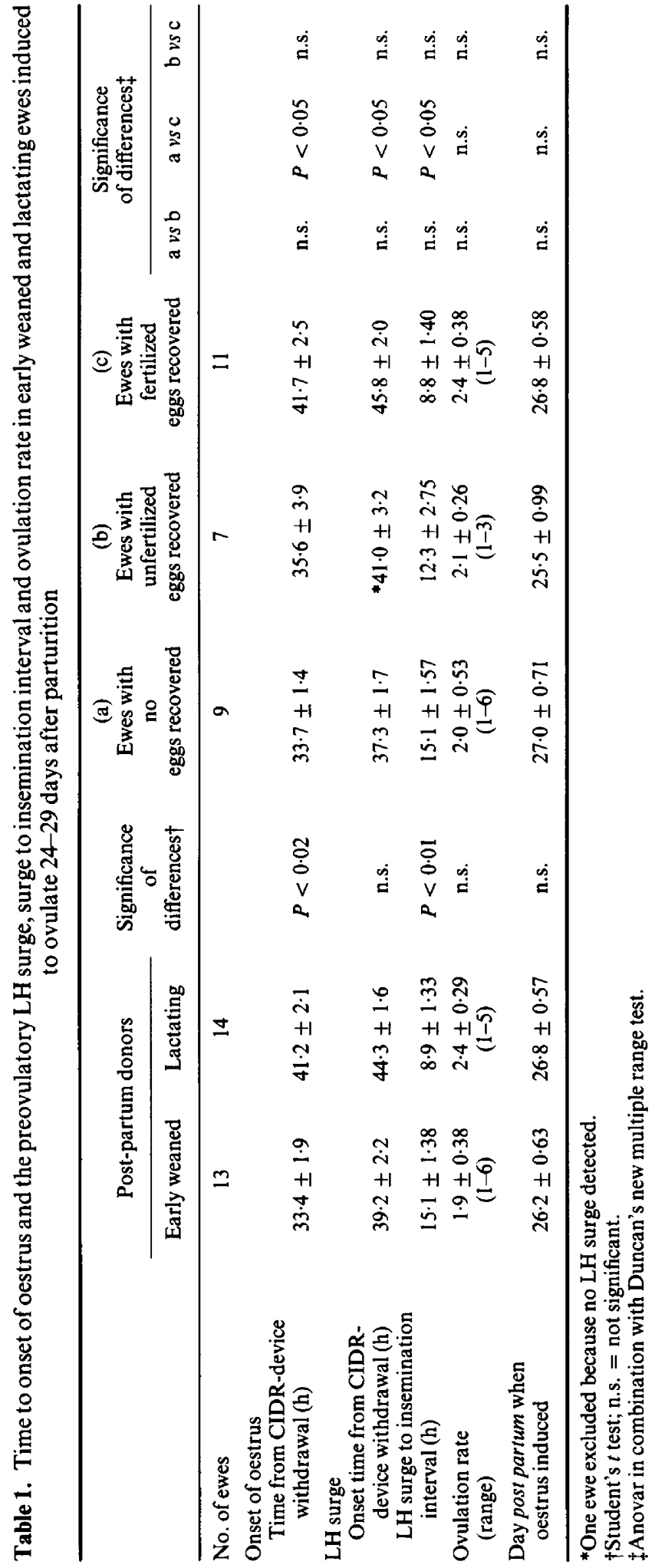


Table 2. Ovum recovery and fertilization rates in early weaned and lactating post-partum donor sheep induced to ovulate between Days 23 and 29 post partum

\begin{tabular}{lccc}
\hline & \multicolumn{2}{c}{ Post-partum donors } & \multirow{2}{*}{$\begin{array}{c}\text { Significance } \\
\text { of } \\
\text { differences* }\end{array}$} \\
\cline { 2 - 3 } & Early weaned & Lactating & \\
\hline $\begin{array}{l}\text { No. of ewes } \\
\text { Flushed for egg recovery }\end{array}$ & 13 & 14 & \\
$\begin{array}{l}\text { Yielding ova } \\
\text { Yielding fertilized ova }\end{array}$ & 7 & 11 & n.s. \\
$\begin{array}{l}\text { No. of ova } \\
\text { Recovered per total } \\
\text { corpora lutea }\end{array}$ & $7 / 24(29.2 \%)$ & $22 / 34(64 \cdot 7 \%)$ & n.s. \\
$\begin{array}{l}\text { Fertilized per total } \\
\text { recovered }\end{array}$ & $4 / 7(57 \cdot 1 \%)$ & $16 / 22(72 \cdot 7 \%)$ & n.s. \\
\hline
\end{tabular}

${ }^{*} \chi^{2}$ test; n.s. $=$ not significant.

Table 3. The number of lambs born to each recipient ewe in relation to the physiological state, previous litter size and time of induced oestrus of her corresponding donor and to the degree of asynchrony between herself and her donor

\begin{tabular}{lccccccc}
\hline $\begin{array}{l}\text { Post-partum } \\
\text { donor ewe } \\
\text { (no.) }\end{array}$ & $\begin{array}{c}\text { Physiological } \\
\text { state } \dagger\end{array}$ & $\begin{array}{c}\text { Donor's } \\
\text { previous } \\
\text { litter } \\
\text { size }\end{array}$ & $\begin{array}{c}\text { Days } \\
\text { post partum } \\
\text { when oestrus } \\
\text { induced }\end{array}$ & $\begin{array}{c}\text { Recipient } \\
\text { ewe } \\
\text { (no.) }\end{array}$ & $\begin{array}{c}\text { Interval between } \\
\text { LH surge onset } \\
\text { of donor and } \\
\text { recipient (h) }\end{array}$ & $\begin{array}{c}\text { No. of } \\
\text { eggs } \\
\text { received }\end{array}$ & $\begin{array}{c}\text { No. of } \\
\text { lambs } \\
\text { born }\end{array}$ \\
\hline 718 & EW & 2 & 24 & 906 & 0 & 1 & 0 \\
733 & EW & 1 & 27 & 706 & 0 & 1 & 1 \\
749 & EW & 2 & 27 & 911 & +12 & 1 & 0 \\
757 & EW & 1 & 28 & 907 & 0 & 1 & 0 \\
719 & L & 3 & 24 & 707 & 0 & 1 & 1 \\
730 & L & 3 & 24 & 697 & -6 & 1 & 1 \\
715 & L & 2 & 27 & 910 & 0 & 2 & 2 \\
& & & & 708 & 0 & 2 & 1 \\
721 & L & 1 & 28 & 909 & +6 & 1 & 1 \\
756 & L & 1 & 28 & 909 & -6 & $2 *$ & 0 \\
751 & L & 3 & 29 & 900 & -6 & 2 & 1 \\
722 & L & 2 & 29 & 915 & -12 & 1 & 0 \\
& & & & 708 & 0 & 1 & 1 \\
& & & & & +12 & 1 & 0 \\
\hline
\end{tabular}

*Eggs assessed as being at an early stage of development.

$† E W$, early weaned; $L$, lactating.

normal luteal function was exhibited by 8 of 13 early weaned ewes and 12 of 14 lactating ewes. Of the 7 ewes exhibiting inadequate luteal function, 2 had a short luteal phase with increased progesterone secretion for 5-6 days only, 3 showed a transient rise in progesterone lasting $24-48 \mathrm{~h}$ and 2 completely failed to secrete progesterone.

Luteal inadequacy was not related to egg recovery or fertilization rate. Indeed, 5 of 7 postpartum ewes exhibiting inadequate luteal function yielded eggs and in 2 of the 5 ewes (756 and 733) these eggs were fertilized and resulted in successful pregnancies when transferred to non-postpartum recipients (Fig. 1; Table 3).

Recipients. Peripheral progesterone profiles throughout the induced oestrous cycle were normal in all 15 recipient ewes. Initially, on Days 1 and 2 of the cycle progesterone concentrations 


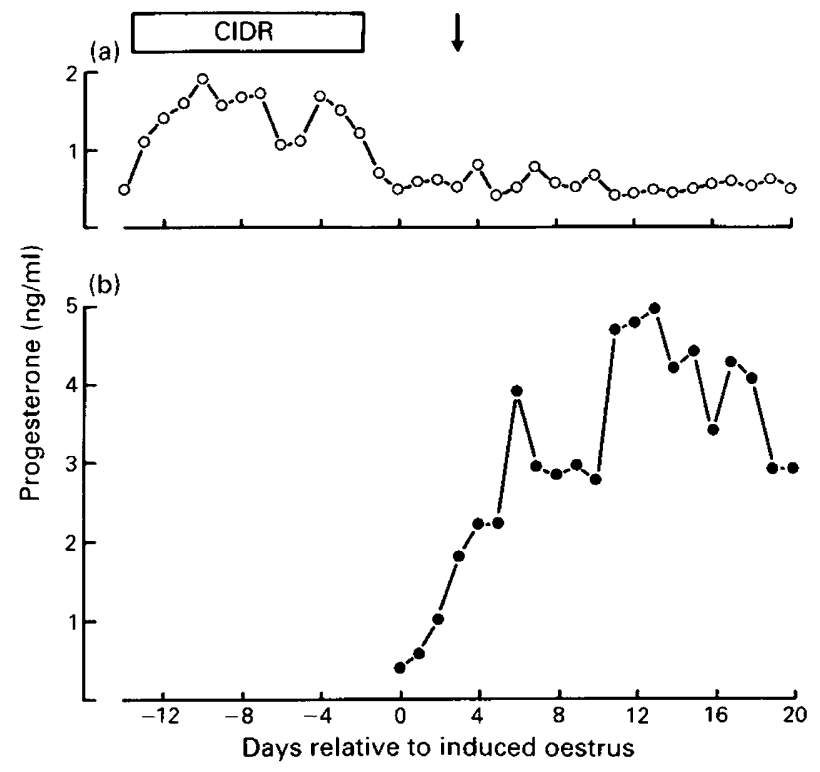

Fig. 1. Daily progesterone concentrations (a) during and after CIDR-device synchronization of oestrus in Ewe 756 induced to ovulate on Day 28 post partum and from which 4 embryos were recovered on Day 3 after the induced oestrus, and (b) after induction of oestrus in Ewe 901 which received 2 embryos from Ewe 756 on Day 3 following oestrus.

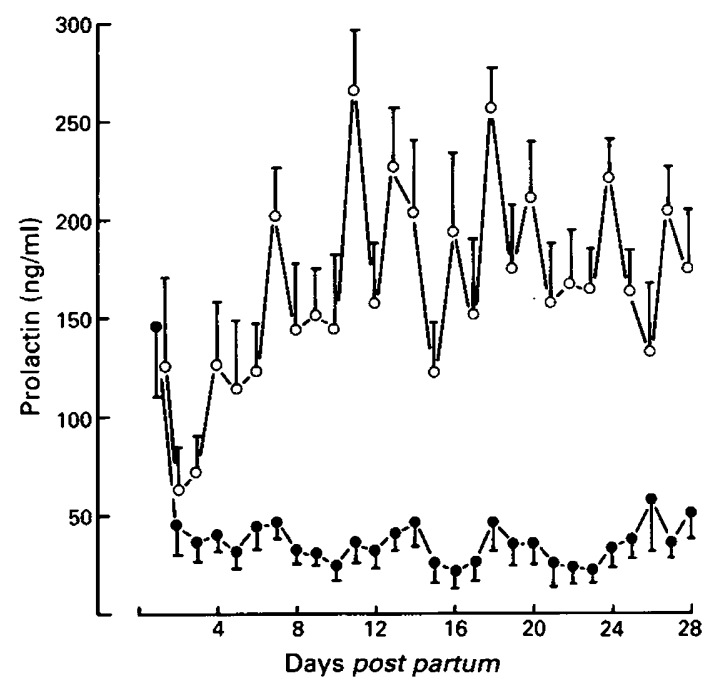

Fig. 2. Changes in daily plasma prolactin concentrations during the breeding season in early weaned $(\odot)$ and lactating donor ewes $(O)$ throughout the first 28 days post partum. Values are mean \pm s.e.m.

were $<0.5 \mathrm{ng} / \mathrm{ml}$, characteristic of oestrus. Values began to rise on Day 3-4 reaching a plateau by Day 7. Progesterone concentrations were not significantly different in pregnant and non-pregnant recipients as measured during Days 3-12 of the luteal phase. In ewes which failed to establish a pregnancy following embryo transfer, progesterone concentrations fell to baseline levels $(<0.5 \mathrm{ng} / \mathrm{ml})$ on Day $15-17$ of the cycle. 


\section{Prolactin concentrations}

Prolactin concentrations fell abruptly within $24 \mathrm{~h}$ of lamb removal in the early weaned ewes and thereafter remained significantly lower $(P<0.001)$ than in lactating ewes throughout the study (Fig. 2). The overall mean prolactin concentrations for the recipient ewes during the first 20 days after induction of oestrus was $26 \cdot 3 \pm 4.35 \mathrm{ng} / \mathrm{ml}$ and individual values were not correlated with whether or not the ewes established a pregnancy following embryo transfer.

\section{Discussion}

The results of the present study demonstrate for the first time that successful fertilization can be achieved, albeit in a small proportion of ewes, following insemination at a synchronized oestrus induced as early as 24 days after parturition. This is 4 days earlier than reported by McKelvey $e t$ al. (1989). Failure of sperm transport through the involuting uterus has been shown to be a major factor limiting the successful establishment of pregnancy in the early post-partum period (Dawe \& Fletcher, 1976; Warren et al., 1986). The present results indicate that this problem can largely be overcome by the deposition of semen directly into the uterine horn. However, the overall fertilization rate of $61 \%$ for those post-partum ewes yielding eggs was considerably lower than the $92 \%$ fertilization rate recorded following the intrauterine insemination of ewes in a once-yearly lambing system (McKelvey et al., 1985). It seems probable, therefore, that semen viability was lower in the early post-partum uterine environment, despite the semen being deposited at the tip of the uterine horn. Indeed, at embryo recovery on Day 3 of the cycle many of the uterine/tubal flushings contained a large amount of debris, suggesting that uterine involution even at the tip of the uterine horn was incomplete. Furthermore, the results of the present study show that the highest fertilization rates occurred in those ewes with a relatively short LH surge to insemination interval (Table 1), implying that for these ewes fertilization occurred before the adverse uterine environment interfered with semen viability.

In the present study, fertilization and ova recovery rates were significantly higher in lactating than in early weaned ewes despite their much higher circulating prolactin concentrations (Fig. 2). This was contrary to expectations as suckling and its associated hyperprolactinaemia are implicated in low fertility in a wide variety of species including sheep (see McNeilly et al., 1982).

Reports on the rate of uterine involution in early weaned versus lactating ewes are conflicting. Call et al. (1976) reported that for ewes lambing during the breeding season the rate of uterine involution was independent of suckling, whilst Honmode (1977) observed that suckling in spring lambing ewes delayed completion of uterine involution by as much as 25 days. Nevertheless, the present study carried out on ewes lambing in their normal breeding season suggests that suckling and its associated release of oxytocin may speed up the rate of uterine involution. Alternatively, the significantly earlier onset of oestrus, longer LH surge to insemination interval and, by implication, longer ovulation to insemination interval in early weaned than in lactating ewes may be detrimental to fertilization and egg recovery for the reasons already discussed. Clearly a range of insemination times would be required to test this hypothesis.

In an earlier study we reported that $30 \%$ of embryos recovered on Day 6 after onset of oestrus from ewes inseminated at 28 days post partum were of poor quality (as assessed morphologically) and considered to be of low viability (McKelvey et al., 1989). Indeed, none of these post-partum ewes maintained their pregnancies after autotransfer. In a subsequent study (Wallace et al., 1989a) we demonstrated that good quality Day-5 embryos donated from ewes in which the interval from parturition was in excess of 150 days had a very low survival rate when transferred into the uterine environment of the early post-partum ewe ( 0 pregnancies in 16 ewes induced to ovulate 21 days post partum and 5 pregnancies in 24 ewes induced to ovulate 35 days post partum). In contrast, the results of the present study show that embryos recovered on Day 3 after oestrus from ewes 
inseminated between 24 and 29 days post partum are viable when transferred to a normal uterine environment. Of the 15 ewes receiving embryos 9 carried pregnancies to term, resulting in the birth of 10 healthy lambs (pregnancy rate, 60\%). This compares favourably with previous studies in which the efficiency of embryo transfer procedures under ideal conditions was assessed as $80 \%$ (Wallace et al., 1989a), and provides strong evidence that an inappropriate uterine environment is one of the major factors limiting the parturition to remating interval of the ewe.

The results of our present study show that the incidence of luteal inadequacy, as assessed by peripheral progesterone concentrations, was greater in early weaned than in lactating ewes and confirms our earlier observation that the suckling stimulus per se does not contribute to abnormal luteal function in early post-partum ewes induced to ovulate during the non-breeding and breeding seasons (Wallace et al., 1989a). In earlier studies using lactating ewes, inadequate luteal function following induction of ovulation 28 days post partum was associated with complete failure of fertilization and low embryo recovery rates on Day 6 after oestrus (Wallace et al., 1989b). An intriguing feature of the present study is that 2 of 7 ewes exhibiting inadequate luteal function (1 lactating and 1 early weaned) yielded fertilized eggs on Day 3 of the cycle and these developed to term following their transfer to the normal uterine environment of ewes $>150$ days from parturition (Fig. 1). This provides us with evidence to question the suggestion (Restall et al., 1977; McNeilly et al., 1982; Wright et al., 1983) that inadequate corpora lutea arise from ovulation of inadequately gonadotrophin-primed follicles which in turn are incapable of producing normal oocytes. In the final analysis the developmental competence of the sheep oocyte is assessed by its ability to undergo fertilization and subsequent embryonic development. Competence is normally acquired by the oocyte while in the preovulatory follicle and relies on a series of follicle cell-oocyte interactions (Crosby et al., 1981), and so any disruption or inadequacy in gonadotrophin priming leading to the formation of inadequate corpora lutea would be unlikely to yield viable fertilized eggs. While the present observations show that this is not always the case, the question remains as to whether these embryos would have continued to develop normally to Days 5 and 6, i.e. to the stage when many embryos are not recovered if the uterus alone is flushed (Tervit \& Havik, 1976), unlike the Day-3 uterine/tubal flushing used in the present study.

In conclusion, we have demonstrated that sheep oocytes can be fertilized using laparoscopic intrauterine insemination as early as 24 days after parturition and that the resulting embryos are viable when recovered on Day 3 after oestrus and transferred to a normal uterine environment.

We thank Miss M. Cheyne, Miss S. Ireland and Mrs I. Robertson for skilled technical assistance; and the NIADDK and Dr A. S. McNeilly for hormone preparations and antiserum.

\section{References}

Call, J.W., Foote, W.C., Eckre, C.D. \& Hulet, C.V. (1976) Post-partum uterine and ovarian changes and oestrous behaviour from lactation effects in normal and hormone-treated ewes. Theriogenology 6, 495-501.

Crosby, I.M., Osborn, J.C. \& Moor, R.M. (1981) Follicle cell regulation of protein synthesis and developmental competence in sheep oocytes. J. Reprod. Fert. 62, $575-582$.

Dawe, S.T. \& Fletcher, I.C. (1976) The effect of post lambing interval on fertilization in lactating ewes treated with progestagen impregnated sponges and gonadotrophin. Proc. Aust. Soc. Anim. Proc. 11, $137-140$.

Djahanbahkch, O., Swanston, I.A., Corrie, J.E.T. \& McNeilly, A.S. (1981) Prediction of ovulation by progesterone. Lancet ii, 1164-1165.
Donald, H.P. \& Russell, W.S. (1970) The relationship between live weight of ewe at mating and weight of newborn lamb. Anim. Prod. 12, 273-280.

Honmode, D. (1977) Post-partum changes in the uterus of ewes. Anim. Breeding Abstr. 45, 384 (Abstr. 3280).

Hunter, G.L., Adams, C.E. \& Rowson, L.E.A. (1955) Interbreed ovum transfer in sheep. J. agric. Sci., Camb. 46, 143-149.

McKelvey, W.A.C., Robinson, J.J., Aitken, R.P. \& Henderson, G. (1985) The evaluation of a laparoscopic insemination technique in ewes. Theriogenology 24, 519-535.

McKelvey, W.A.C., Wallace, J.M., Robinson, J.J. \& Aitken, R.P. (1989) Studies on increasing breeding frequency in the ewe. 1. The fertilization of ova during the early post-partum period. Anim. Reprod. Sci. 18, 1-12. 
Mcleod, B.J., Haresign, W. \& Lamming, G.E. (1983) Induction of ovulation in seasonally anoestrous ewes by continuous infusion of low doses of GnRH. $J$. Reprod. Fert. 68, 489-495.

McNeilly, A.S. \& Andrews, P. (1974) Purification and characterization of caprine prolactin. $J$. Endocr. 60, 359-367.

McNeilly, A.S., Glasier, A., Jonassen, J. \& Howie, P.W. (1982) Evidence for direct inhibition of ovarian function by prolactin. J. Reprod. Fert. 65, 559-569.

McNeilly, A.S., Jonassen, J.A. \& Fraser, H.M. (1986) Suppression of follicular development after chronic LHRH immunoneutralization in the ewe. J. Reprod. Fert. 76, 481-490.

Restall, B.J., Kearins, R.D. \& Starr, B.G. (1977) Studies of pituitary function in lactating ewes. J. Reprod. Fert. 49, 291-296.

Tervit, H.R. \& Havik, P.G. (1976) A modified technique for flushing ova from the sheep uterus. N.Z. vet. J. 24, 138-140.
Wallace, J.M., Robinson, J.J. \& Aitken, R.P. (1989a) Does inadequate luteal function limit the establishment of pregnancy in the early post-partum ewe? $J$. Reprod. Fert. 85, 229-240.

Wallace, J.M., Robinson, J.J., McKelvey, W.A.C. \& Aitken, R.P. (1989b) Studies on increasing breeding frequency in the ewe. 2. The endocrine status of lactating ewes induced to ovulate 28,35 or 42 days post-partum. Anim. Reprod. Sci. 18, (in press).

Warren, J.E., Kiesling, D.O. \& Akinbami, M.A. (1986) Fertilization rates in early post-partum ewes. The Shepherd 31, 33.

Wright, P.J., Geytenbeek, P.E., Clarke, I.J. \& Findlay, J.K. (1983) LH release and luteal function in postpartum acyclic ewes after the pulsatile administration of LH-RH. J. Reprod. Fert. 67, 257-262.

Received 9 November 1988 